\title{
Microbial methanol uptake in northeast Atlantic waters
}

\author{
Joanna L Dixon, Rachael Beale and Philip D Nightingale \\ Plymouth Marine Laboratory, Prospect Place, West Hoe, Plymouth, Devon, UK
}

\begin{abstract}
Methanol is the predominant oxygenated volatile organic compound in the troposphere, where it can significantly influence the oxidising capacity of the atmosphere. However, we do not understand which processes control oceanic concentrations, and hence, whether the oceans are a source or a sink to the atmosphere. We report the first methanol loss rates in seawater by demonstrating that ${ }^{14} \mathrm{C}$-labelled methanol can be used to determine microbial uptake into particulate biomass, and oxidation to ${ }^{14} \mathrm{CO}_{2}$. We have found that methanol is used predominantly as a microbial energy source, but also demonstrated its use as a carbon source. We report biological methanol oxidation rates between 2.1 and $8.4 \mathrm{nmol} \mathrm{I}^{-1}$ day $^{-1}$ in surface seawater of the northeast Atlantic. Kinetic experiments predict a $V_{\max }$ of up to $29 \mathrm{nmol} \mathrm{I}^{-1}$ day $^{-1}$, with a high affinity $K_{\mathrm{m}}$ constant of $9.3 \mathrm{nM}$ in more productive coastal waters. We report surface concentrations of methanol in the western English channel of $97 \pm 8 \mathrm{nM}(n=4)$ between May and June 2010, and for the wider temperate North Atlantic waters of $70 \pm 13 \mathrm{nM}(n=6)$. The biological turnover time of methanol has been estimated between 7 and 33 days, although kinetic experiments suggest a 7-day turnover in more productive shelf waters. Methanol uptake rates into microbial particles significantly correlated with bacterial and phytoplankton parameters, suggesting that it could be used as a carbon source by some bacteria and possibly some mixotrophic eukaryotes. Our results provide the first methanol loss rates from seawater, which will improve the understanding of the global methanol budget.

The ISME Journal (2011) 5, 704-716; doi:10.1038/ismej.2010.169; published online 11 November 2010

Subject Category: geomicrobiology and microbial contributions to geochemical cycles

Keywords: bacteria; kinetics; methanol uptake; northeast Atlantic; phytoplankton; radioactive labelling
\end{abstract}

\section{Introduction}

Methanol is the predominant oxygenated volatile organic compound in the troposphere, and is thought to have an important role in the chemistry of the atmosphere by sequestering nitrogen oxides, and by providing $\mathrm{HO}_{\mathrm{x}}$ radicals through photolysis (Singh et al., 1995; Wennberg et al., 1998), thus influencing the oxidising capacity and ozone formation (Singh et al., 2001). However, the role of the oceans in acting as a source (Singh et al., 2000; Heikes et al., 2002) or sink (Carpenter et al., 2004; Williams et al., 2004) of methanol (and other oxygenated volatile organic compounds) to the atmosphere is uncertain. Oceanic deposition of methanol has been inferred from several modelling studies (Galbally and Kirstine, 2002; Heikes et al., 2002; Singh et al., 2003), and by Carpenter et al. (2004), who demonstrated an anti-correlation between atmospheric methanol concentrations and wind speed at Mace Head (Ireland), which suggested a net air to sea flux of methanol over the northeast

Correspondence: JL Dixon, Plymouth Marine Laboratory, Prospect Place, West Hoe, Plymouth, Devon, PL1 3DH, UK.

E-mail: jod@pml.ac.uk

Received 27 May 2010; revised 28 September 2010; accepted 29 September 2010; published online 11 November 2010
Atlantic Ocean. However, air sea flux estimates are uncertain because of the analytical difficulties in reliably determining the concentration of methanol, due to its high solubility in seawater. The only published dataset with methanol measurements in seawater and air also suggest an influx of methanol to the ocean in the tropical Atlantic (Williams et al., 2004). Little is known about how methanol is produced and/or consumed in seawater. Biological production of methanol by phytoplankton cultures during exponential and stationary phase growth has been proposed (Milne et al., 1995; Heikes et al., 2002), as have bacterial sources via transformation of algal carbohydrates within the aerobic upper ocean, (Sieburth and Keller, 1989) but no measurements have been made to support these hypotheses. An early gas chromatography mass spectrometry study of water surrounding intact macroalgal samples showed that methanol, amongst others oxygenated volatile organic compounds, were present at much greater levels than ambient seawater (Nightingale, 1991). Possible oceanic loss processes include photochemical destruction and microbial uptake, although methanol is thought to be long lived in seawater with respect to photochemical oxidation (Heikes et al., 2002). Kiene (1993) suggested methanol uptake as a carbon and energy source by oceanic methylotrophic organisms, but no rate 
measurements have ever been reported. Methylotrophic organisms, by their definition, must synthesise all their cellular components from one carbon $\left(\mathrm{C}_{1}\right)$ compounds, such as methanol, methylated sulphur species, methylated amines and so on, wherein formaldehyde is the common central metabolite (Murrell and McDonald, 2000). Most organisms that are capable of using methanol are thought to contain an enzyme called methanol dehydrogenase for oxidising methanol to formaldehyde in the cell (Smith and Murrell, 2009). From molecular studies, a diverse range of both prokaryotes and eukaryotes are thought able to use methanol for growth (Murrell and McDonald, 2000). However, there are no published measurements of methanol uptake rates in the marine environment.

The aim of this study was to make the first ever measurements of the biological consumption of methanol in marine waters, and to determine what proportion of the uptake was attributable to either cell growth or energy use.

\section{Materials and methods}

We have modified a radiochemical technique that uses the addition of ${ }^{14} \mathrm{C}$-labelled methanol $\left({ }^{14} \mathrm{CH}_{3} \mathrm{OH}\right)$ to seawater to determine the microbial conversion of methanol into particulate cell biomass, and oxidation of methanol to carbon dioxide (used as an energy source).

\section{Sample collection}

Surface water samples $(\leqslant 10 \mathrm{~m})$ for time course, kinetic and addition experiments (Table 1) were collected from a long term monitoring station, situated approximately 10 nautical miles south-west of Plymouth, called L4 (Figure 1: $50.25 \mathrm{~N}, 04.22 \mathrm{~W}$, water depth $\sim 55 \mathrm{~m}$ ). Samples were pumped directly into acid-washed quartz Duran bottles and stored in the dark for the 2-3 h transit back to the laboratory. Surface seawater samples were also collected from the northeast Atlantic (Figure 1) during a research cruise carried out as part of the UK Surface Ocean Lower Atmosphere Study aboard the Royal Research Ship Discovery (D320, 16 June-17 July 2007). Samples were either collected using $20 \mathrm{l}$ Niskin bottles (General Oceanics, Miami, FL, USA) deployed on a rosette equipped with a Seabird (Sea-Bird Electronics, Inc., Bellevue, WA, USA) conductivity, temperature and depth sensors, or were pumped while underway from an approximate depth of $5 \mathrm{~m}$ using a peristaltic pump. The seawater was collected directly into acid washed

Table 1 Summary of experiments. All samples were collected from the surface $(\leqslant 10 \mathrm{~m})$

\begin{tabular}{|c|c|c|c|c|c|c|c|c|}
\hline Date & Location & $\begin{array}{c}\text { Map } \\
\text { location }^{\mathrm{a}}\end{array}$ & $\begin{array}{c}\text { Temperature } \\
\left({ }^{\circ} \mathrm{C}\right)\end{array}$ & $\begin{array}{l}\text { Chlorophyll } \\
\mathrm{a}^{\mathrm{b}}\left(\mu g \mathrm{I}^{-1}\right)\end{array}$ & $\begin{array}{l}\text { Sample } \\
\text { volume }^{\mathrm{c}} \\
\quad(\mathrm{ml})\end{array}$ & $\begin{array}{c}\text { Added } \\
{ }^{14} C \text {-methanol } \\
(n M)\end{array}$ & $\begin{array}{l}\text { Incubation } \\
\text { time }(h)\end{array}$ & $\begin{array}{l}\text { Experiment } \\
\text { description }\end{array}$ \\
\hline \multicolumn{9}{|l|}{$L 4$} \\
\hline 06/06/06 & $50.25^{\circ} \mathrm{N} 04.22^{\circ} \mathrm{W}$ & L4 & $13-14$ & 1.2 & 1.7 & 10 and 100 & $0.1-120$ & Time course \\
\hline $25 / 09 / 06^{d}$ & $50.25^{\circ} \mathrm{N} 04.22^{\circ} \mathrm{W}$ & L4 & 17.0 & 2.7 & 1.7 & $\begin{array}{l}5-100 \\
100\end{array}$ & $\begin{array}{r}3,24 \\
24\end{array}$ & $\begin{array}{l}\text { Kinetic }\left(V_{\max }\right) \\
\text { Prokaryotic/eukaryotic } \\
\text { inhibitor }\end{array}$ \\
\hline 03/10/06 & $50.25^{\circ} \mathrm{N} 04.22^{\circ} \mathrm{W}$ & L4 & 17.0 & 3.8 & 1.7 & 100 & $1-120$ & $\begin{array}{l}\text { Substrate addition and } \\
\text { inhibitor }\end{array}$ \\
\hline \multicolumn{9}{|c|}{ Northeast Atlantic } \\
\hline $17 / 06 / 07$ & $49.04{ }^{\circ} \mathrm{N}, 09.88^{\circ} \mathrm{W}$ & 1 & 15.5 & $\sim 0.5$ & 1.7 & 10 & $0.1-24$ & Time course \\
\hline $20 / 06 / 07$ & $43.38^{\circ} \mathrm{N}, 18.42^{\circ} \mathrm{W}$ & 2 & 16.7 & $<0.2$ & 50 & $\begin{array}{c}10 \\
10-200\end{array}$ & $\begin{array}{c}0.03-26 \\
1-1.6\end{array}$ & $\begin{array}{l}\text { Time course } \\
\text { Kinetic }\left(V_{\max }\right)\end{array}$ \\
\hline 08/07/07 & $42.73^{\circ} \mathrm{N}, 16.25^{\circ} \mathrm{W}$ & 3 & 18.1 & $<0.2$ & $\begin{array}{r}50 \\
100\end{array}$ & $\begin{array}{l}1-250 \\
100\end{array}$ & $\begin{array}{c}24 \\
0.2-48\end{array}$ & $\begin{array}{l}\text { Kinetic }\left(V_{\max }\right) \\
\text { Time course }\end{array}$ \\
\hline $22 / 06 / 07$ & $43.70^{\circ} \mathrm{N}, 18.13^{\circ} \mathrm{W}$ & 4 & 16.7 & $<0.2$ & 50 & 17.5 & 3 & Particulate uptake \\
\hline $24 / 06 / 07$ & $43.54{ }^{\circ} \mathrm{N}, 18.04^{\circ} \mathrm{W}$ & 5 & 17.1 & $<0.2$ & 50 & 17.5 & 25 & Particulate uptake \\
\hline $27 / 06 / 07$ & $43.36^{\circ} \mathrm{N}, 17.85^{\circ} \mathrm{W}$ & 6 & 16.8 & $<0.2$ & 50 & 17.5 & 25 & Particulate uptake \\
\hline $28 / 06 / 07$ & $43.25^{\circ} \mathrm{N}, 17.83^{\circ} \mathrm{W}$ & 7 & 16.9 & $<0.2$ & 35 & 25 & 25 & Particulate uptake \\
\hline $12 / 07 / 07$ & $42.67^{\circ} \mathrm{N}, 16.11^{\circ} \mathrm{W}$ & $7 a$ & 16.9 & $<0.2$ & 100 & 52 & 9 & Diel experiment (24 h) \\
\hline $14 / 07 / 07$ & $46.29^{\circ} \mathrm{N}, 14.89^{\circ} \mathrm{W}$ & 8 & 17.1 & $0.3-0.6$ & 50 & 52 & 24 & Particulate uptake \\
\hline & $46.64^{\circ} \mathrm{N}, 14.80^{\circ} \mathrm{W}$ & 9 & 16.9 & $0.3-0.6$ & 50 & 52 & 22 & Particulate uptake \\
\hline & $47.03{ }^{\circ} \mathrm{N}, 14.71^{\circ} \mathrm{W}$ & 10 & 16.8 & $0.3-0.6$ & 50 & 52 & 19 & Particulate uptake \\
\hline & $47.36^{\circ} \mathrm{N}, 14.64^{\circ} \mathrm{W}$ & 11 & 17.0 & $0.3-0.6$ & 50 & 52 & 18 & Particulate uptake \\
\hline $16 / 07 / 07$ & $54.21{ }^{\circ} \mathrm{N}, 12.69^{\circ} \mathrm{W}$ & 12 & 15.0 & $0.7-1.0$ & 50 & 52 & 20 & Particulate uptake \\
\hline & $54.20^{\circ} \mathrm{N}, 12.70^{\circ} \mathrm{W}$ & 13 & 15.1 & $0.7-1.0$ & 50 & 52 & 18 & Particulate uptake \\
\hline & $54.17^{\circ} \mathrm{N}, 12.74^{\circ} \mathrm{W}$ & 14 & 15.0 & $0.7-1.0$ & 50 & 52 & 15 & Particulate uptake \\
\hline
\end{tabular}

${ }^{\text {a Refer to Figure } 1 .}$

burface concentrations of chlorophyll $a$ at L4 were obtained from the L4 database, which is provided by the Plymouth Marine Laboratory Western Channel Observatory, and from the northeast Atlantic were derived from a chlorophyll $a$ composite image of Aqua-MODIS data from 16 June to 16 July 2007.

${ }^{\mathrm{c}}$ Volume of sample used to determine methanol uptake into particles.

dSeawater sampled during a dinoflagellate bloom of Prorocentrum minimum. 


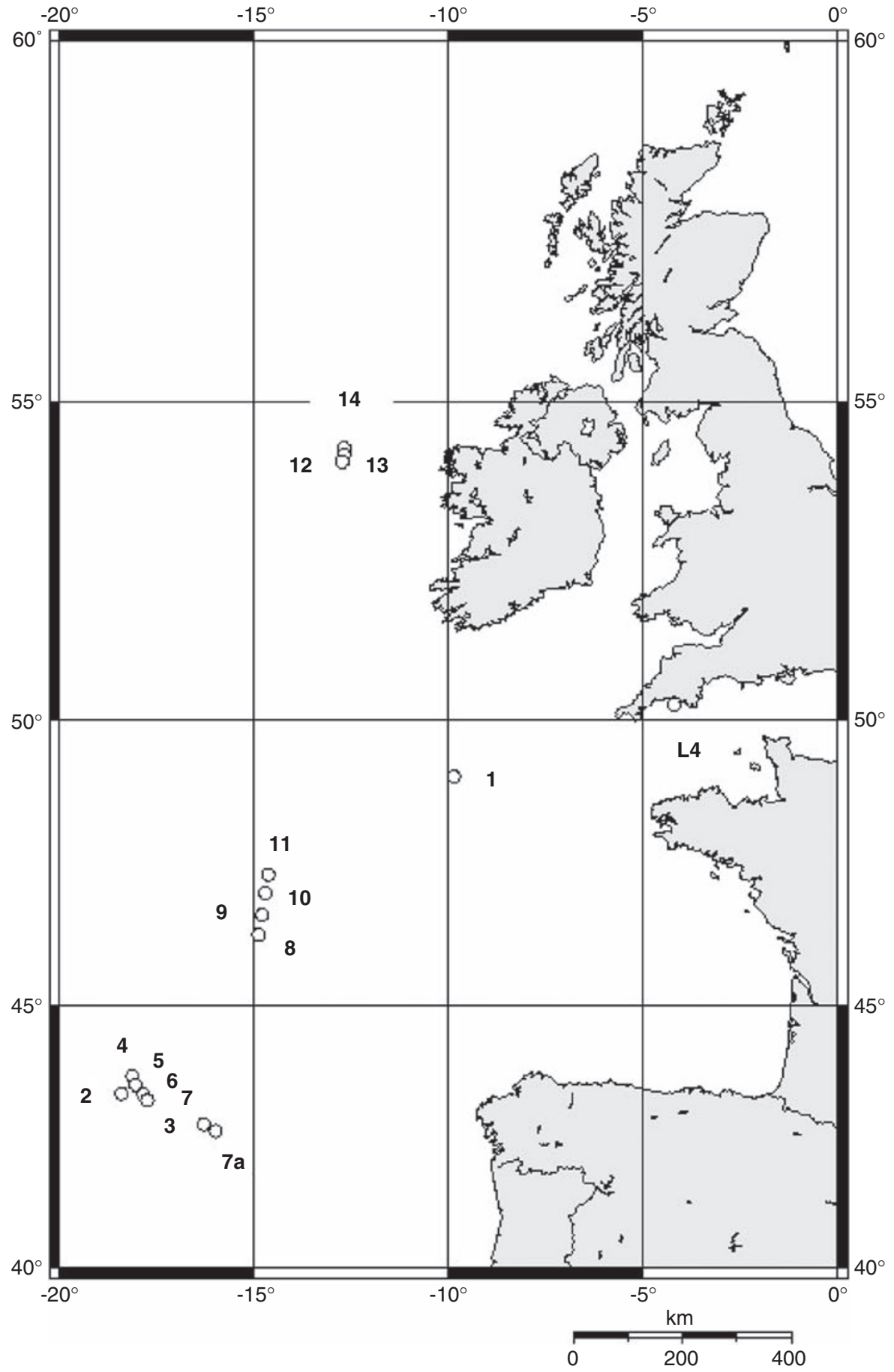

Figure 1 Sampling locations (software used: http://www.aquarius.ifm-geomar.de).

polycarbonate bottles and experiments were started typically within $1 \mathrm{~h}$ of sampling. The labelled ${ }^{14} \mathrm{C}$ methanol was purchased from American Radiolabeled Chemicals Inc. (Saint Louis, MO, USA) with a specific activity of $57.1 \mathrm{mCimmol}^{-1}$. Primary stocks were diluted 1:10 with $18 \mathrm{M} \Omega$ milli $Q$ water (Millipore, Billerica, MA, USA) $\left(0.1 \mathrm{mCi} \mathrm{ml}^{-1}\right)$ and were stored in gas tight vials in the dark at $4{ }^{\circ} \mathrm{C}$. Stability and storage trials suggest a loss in activity of $<10 \%$ over 12 months. Addition volumes of ${ }^{14} \mathrm{C}$ methanol to seawater samples were always $<1 \%$ of the sample volume and typically $\leqslant 12 \%$ of the label was used during incubations $\leqslant 24 \mathrm{~h}$.

\section{Linear time course experiments}

Seawater samples were treated with between 10 and $100 \mathrm{nM}{ }^{14} \mathrm{CH}_{3} \mathrm{OH}$ final added concentration (1494-13434 disintegrations per minute per ml) depending on the experiment (Table 1). Samples 
were incubated in acid washed polycarbonate bottles in the dark for between 0.1 and $120 \mathrm{~h}$ at in situ temperature. At selected times, triplicate subsamples to assess uptake into particulate cell biomass and total oxidation to ${ }^{14} \mathrm{CO}_{2}$ were taken. For uptake into particles during L4 experiments, $1.7 \mathrm{ml}$ samples were placed in $2 \mathrm{ml}$ screw top sterile polypropylene micro centrifuge tubes and fixed with $100 \mu$ trichloroacetic acid (TCA, 5\% final concentration). Samples were centrifuged $(16000 \times \mathrm{g})$ for $10 \mathrm{~min}$, aspirated and washed with $80 \%$ ethanol. This process was repeated twice, and after the third aspiration, liquid scintillation fluid (Optiphase HiSafe III; Perkin-Elmer, Buckinghamshire, UK) was added and the sample mixed and placed in the dark overnight to allow chemiluminiscence to subside before counting on a liquid scintillation counter (Tri-carb 3100, Perkin-Elmer). This approach is similar to the leucine incorporation method modified for microcentrifuge tubes (Smith and Azam, 1992).

During the UK Surface Ocean Lower Atmosphere Study research cruise, larger sampling volumes between 50 and $100 \mathrm{ml}$ were used for methanol uptake into particles to increase the sample counts (Table 1). Seawater samples were filtered onto $0.2 \mu \mathrm{m}$ Supor (Pall Corporation, Portsmouth, Hampshire, UK) (polyethersulfone) filter membranes with a vacuum of $<10 \mathrm{~cm} \mathrm{Hg}$. The filters were rinsed three times with $2-3 \mathrm{ml}$ of $80 \%$ ethanol, placed in a $4 \mathrm{ml}$ scintillation vial and dried overnight in a desiccator, before the addition of scintillation fluid. Radioactivity retained on the filters was measured as disintegrations per minute (DPM) onboard ship using a liquid scintillation counter as above. Total oxidation of ${ }^{14} \mathrm{CH}_{3} \mathrm{OH}$ to ${ }^{14} \mathrm{CO}_{2}$ was determined in triplicate by pipetting $1 \mathrm{ml}$ samples into $2 \mathrm{ml}$ microcentrifuge tubes and adding $0.5 \mathrm{ml}$ of $\mathrm{SrCl}_{2} \cdot 6 \mathrm{H}_{2} \mathrm{O}(1 \mathrm{M})$, to precipitate the ${ }^{14} \mathrm{CO}_{2}$ as $\mathrm{Sr}^{14} \mathrm{CO}_{3}, 20 \mu \mathrm{l}$ of $\mathrm{NaOH}$ $(1 \mathrm{M})$, to neutralise the $\mathrm{HCl}$ produced, and $100 \mu \mathrm{l}$ of $\mathrm{Na}_{2} \mathrm{CO}_{3}(1 \mathrm{M})$, to ensure adequate pellet formation (Connell et al., 1997; Goodwin et al., 1998). After centrifugation the supernatant was aspirated, the pellet washed twice with ethanol $(80 \%)$, resuspended in $1 \mathrm{ml}$ of concentrated $\mathrm{NaOH}$ solution $(\sim 10 \mathrm{nM})$ that had been adjusted to a $\mathrm{pH}$ of 11.7 , before addition of Optiphase HiSafe III to create a slurry. The samples were vortex mixed and stored in the dark for $>24 \mathrm{~h}$ before being analysed on the scintillation counter. This period ensures that any chemiluminescence arising from interactions between the $\mathrm{NaOH}$ added and the Optiphase scintillant subside (Kiene and Hoffmann Williams, 1998).

\section{Kinetic determinations}

Microbial methanol kinetics were investigated at L4 using 1.7 and $1.0 \mathrm{ml}$ seawater samples to determine uptake into particulate biomass and total oxidation, respectively. Individual samples received an addition of ${ }^{14} \mathrm{CH}_{3} \mathrm{OH}$, and a series of tubes for both uptake into particles and total oxidation were treated to yield a range of added ${ }^{14} \mathrm{CH}_{3} \mathrm{OH}$ between 5 and $100 \mathrm{nM}$. Samples were incubated in screw topped, O-ring sealed microtubes in the dark at in situ temperature (Table 1). Triplicate replicates from each methanol concentration were processed, as detailed above, after incubation periods of 3 and $24 \mathrm{~h}$.

The kinetics of methanol uptake into the particulate phase only was determined at stations 2 and 3 in the northeast Atlantic, where $50 \mathrm{ml}$ sample aliquots were incubated in the dark at in situ temperature, after additions of ${ }^{14} \mathrm{CH}_{3} \mathrm{OH}$ between 1 and $250 \mathrm{nM}$, with more emphasis on the lower range (1-50 nM). Incubations were terminated after approximately $1 \mathrm{~h}$ at station 2 , and $24 \mathrm{~h}$ at station 3 by gentle vacuum filtration onto Supor filters. These filters have been reported to give the best retention of particulate material $>0.2 \mu \mathrm{m}$, compared with Nuclepore or Anopore filters (Whatman plc, Maidstone, Kent, UK), with minimal blanks (Kiene and Hoffmann Williams, 1998). $V_{\max }$ and $K_{\mathrm{m}}$ (Michaelis constant) were calculated using the Lineweaver-Burk transformation.

Substrate addition and inhibitor experiments

Addition experiments. The effects of adding trimethylamine (TMA; 10-100 $\mu \mathrm{M}$ ) and dimethylsulphoxide (10 and $100 \mu \mathrm{M})$ on rates of methanol oxidation and uptake into particles were assessed on surface seawater samples from the coastal station L4. Triplicate samples for methanol oxidation $(1.0 \mathrm{ml}$ sample volume) and uptake into particulate cellular biomass $(1.7 \mathrm{ml}$ sample volume), were incubated in the dark, at in situ temperature, over a time series varying between 1 and $120 \mathrm{~h}$. All the additions were made immediately before adding the ${ }^{14}$ C-labelled methanol.

\section{Cycloheximide and chloroamphenicol inhibitor experiments}

The extent to which prokaryotes (assumed to be mainly bacteria) and eukaryotes (phytoplankton) use methanol as an energy and carbon source was investigated on surface seawater samples collected during a dinoflagellate bloom of Prorocentrum minimum at the coastal station L4. Chloroamphenicol $\left(20 \mu \mathrm{g} \mathrm{ml}^{-1}\right)$ and cycloheximide $(483 \mu \mathrm{g}$ $\mathrm{ml}^{-1}$ ) were used to inhibit prokaryotic and eukaryotic protein synthesis, respectively (Goodwin et al., 1998). Methanol oxidation and uptake into particulate cellular biomass was measured in triplicate $1 \mathrm{ml}$ and $1.7 \mathrm{ml}$ samples, respectively, and incubations terminated after $24 \mathrm{~h}$. Seawater samples were processed as described previously.

Surface uptake in the northeast Atlantic

At a series of stations in the northeast Atlantic, rates of methanol uptake into particulate cellular biomass 
were determined using $50 \mathrm{ml}$ seawater samples collected from the surface $(<10 \mathrm{~m}$; Table 1$)$ and processed as detailed previously. The data is reported as apparent rate constants, $k\left(\right.$ day $\left.^{-1}\right)$ calculated from a ratio of the ${ }^{14} \mathrm{C}$ counts collected in either the particulate phase or as ${ }^{14} \mathrm{CO}_{2}\left(\mathrm{nCi} \mathrm{ml}^{-1}\right.$ day $^{-1}$ ) divided by total ${ }^{14} \mathrm{CH}_{3} \mathrm{OH}$ added to the sample $\left(\mathrm{nCi} \mathrm{ml}^{-1}\right)$. All rate constants were corrected by subtracting killed sample (TCA, $5 \%$ final concentration) counts to correct for passive surface sorption. Rates of bacterial protein production and the numbers of heterotrophic bacteria, Prochlorococcus spp, Synechococcus spp and picoeukaryotes were also determined to investigate any trends. Bacterial protein production was determined by measuring the incorporation of ${ }^{3} \mathrm{H}$-leucine $(20 \mathrm{nM}$ final concentration) into bacterial protein on $1.7 \mathrm{ml}$ seawater samples following the method of Smith and Azam (1992). The numbers of bacterioplankton cells were determined by flow cytometry on SYBR green I DNA-stained cells from $1.8 \mathrm{ml}$ seawater samples fixed in paraformaldehyde (5\%, final concentration), flash frozen in liquid nitrogen immediately after fixation, and stored frozen at $-80{ }^{\circ} \mathrm{C}$ (Marie et al., 1997). Numbers of Prochlorococcus spp, Synechococcus spp and picoeukaryotes were analysed on unstained samples by flow cytometry (Zubkov et al., 2000). Surface concentrations of chlorophyll $a$ were estimated using a composite Aqua-MODIS chlorophyll a remotely sensed image for the cruise duration (16 June-16 July 2007), as unfortunately the continuous surface fluorometer onboard the ship was not working correctly. Chlorophyll a samples from L4 were determined by fluorometric analysis of acetoneextracted pigments (Holm-Hansen et al., 1965).

\section{Results}

Linear time course experiments

When nanomolar concentrations of ${ }^{14} \mathrm{CH}_{3} \mathrm{OH}$ were added to coastal seawater samples from L4, and oceanic samples from the northeast Atlantic, radioactive carbon was incorporated into particulate cellular material and expired to ${ }^{14} \mathrm{CO}_{2}$ (Figure 2), and thus used as a carbon and an energy source.
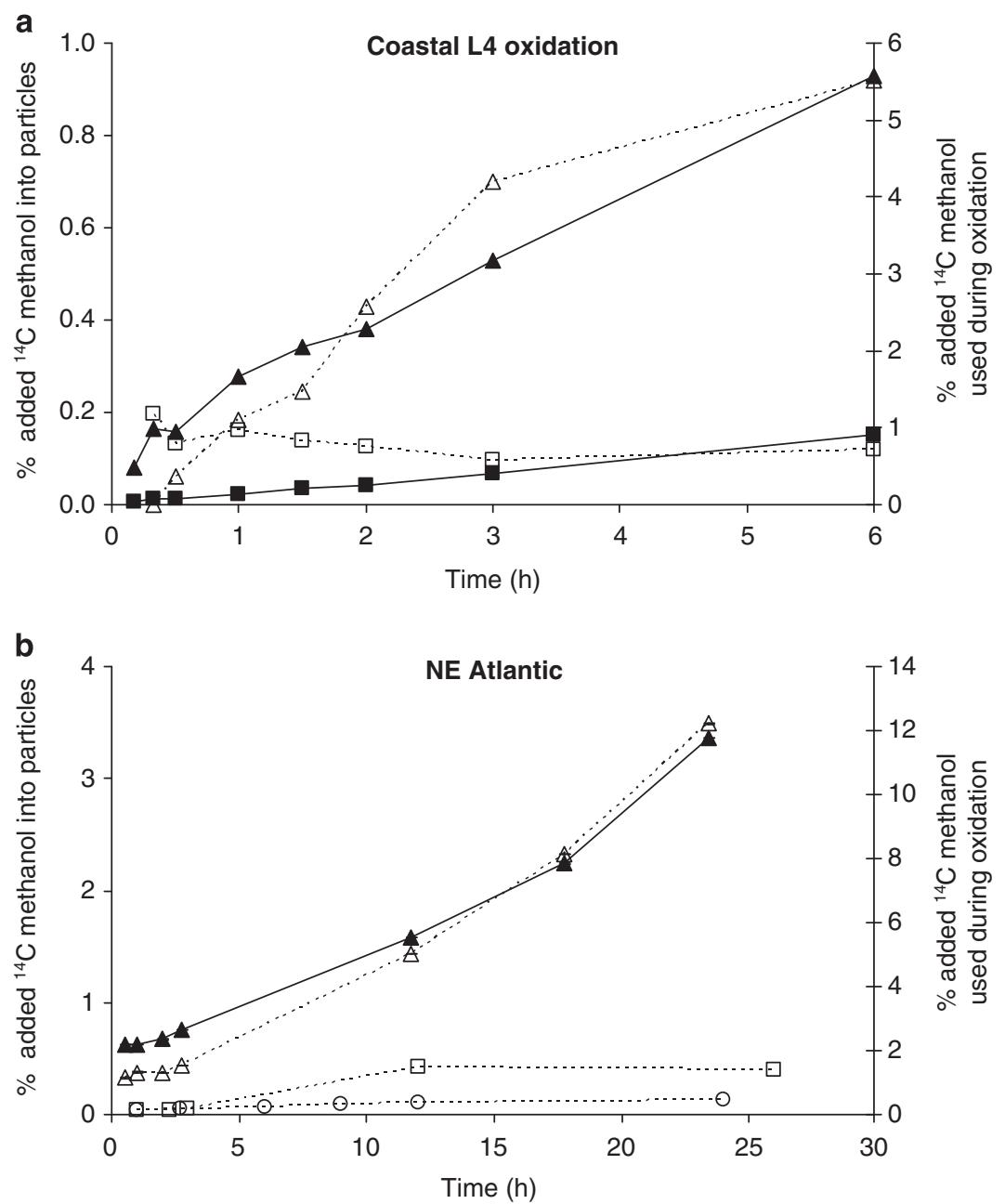

Figure 2 Time course experiments showing the \% added ${ }^{14} \mathrm{CH}_{3} \mathrm{OH}$ that was used either during oxidation (solid symbols) or uptake

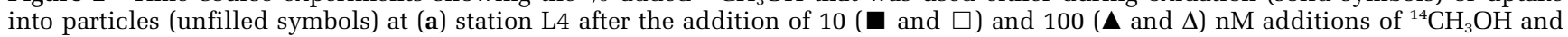
(b) stations $1(\boldsymbol{\Lambda}$ and $\triangle), 2(\square)$ and $3(\bigcirc)$ in the northeast (NE) Atlantic. For experimental details, refer to Table 1. 
Table 2 Calculated total methanol oxidation rates and turnover times

\begin{tabular}{lcccc}
\hline Stations $^{\mathrm{a}}$ & $\begin{array}{c}{ }^{14} \mathrm{CH}_{3} \mathrm{OH} \text { rate constant, } \\
\mathrm{k}\left(\text { day }{ }^{-1}\right)\end{array}$ & $\begin{array}{c}\text { Total }^{14} \mathrm{CH}_{3} \mathrm{OH} \text { oxidation rate } \\
\left(\mathrm{nmol} \mathrm{I}^{-1} \text { day }{ }^{-1}\right)\end{array}$ & $\begin{array}{c}\text { Assumed } \\
{\left[\mathrm{CH}_{3} \mathrm{OH}\right](\mathrm{nM})}\end{array}$ & Turnover time (days) \\
\hline Coastal station, L4 $^{\mathrm{b}}$ & $0.04-0.18$ & $4.2-8.4$ & 97 & 70 \\
On-shelf, station 1 & 0.075 & 2.9 & 70 & 24 \\
Off-shelf, station 7a $^{\mathrm{c}}$ & $0.007-0.022$ & $2.1-6.1$ & 70 \\
\hline
\end{tabular}

a See Figure 1.

${ }^{b}$ Range derived from two linear time course experiments at $\mathrm{L} 4$ using 10 and $100 \mathrm{nM}$ added ${ }^{14} \mathrm{CH}_{3} \mathrm{OH}$.

${ }^{\mathrm{C}}$ Range in methanol oxidation rates determined whilst sampling hourly during a 24 -h surface diel experiment.

At the coastal station L4, methanol oxidation was linear for up to $48 \mathrm{~h}$ after the addition of $10 \mathrm{nM}$ ${ }^{14} \mathrm{CH}_{3} \mathrm{OH}$ (only data up to $6 \mathrm{~h}$ incubation is shown in Figure 2a). The rate of methanol oxidised to ${ }^{14} \mathrm{CO}_{2}$ was $0.01 \mathrm{nCi} \mathrm{ml}^{-1} \mathrm{~h}^{-1}\left(R^{2}=0.999, n=9\right)$, after which $33 \%$ of the added substrate had been oxidised after $48 \mathrm{~h}$ incubation. After the addition of $100 \mathrm{nM}$ ${ }^{14} \mathrm{CH}_{3} \mathrm{OH}$, methanol oxidation was linear for up to 5 days at an increased rate of $0.02 \mathrm{nCiml}^{-1} \mathrm{~h}^{-1}$ $\left(R^{2}=0.999, n=10\right)$, after which $20 \%$ of the added label had been oxidised.

Methanol uptake into particles after the addition of $10 \mathrm{nM}^{14} \mathrm{CH}_{3} \mathrm{OH}$ was also linear up to $48 \mathrm{~h}$, but with a lower rate of $0.005 \mathrm{nCi} \mathrm{ml}^{-1} \mathrm{~h}^{-1}\left(R^{2}=0.997\right.$, $n=6$ ), after which $15 \%$ of the added substrate had been used. However, after the addition of $100 \mathrm{nM}$ ${ }^{14} \mathrm{CH}_{3} \mathrm{OH}$, there was no increase in added label counted in the particulate phase over time. Approximately $0.2 \%$ of the added substrate was associated with particles $>0.2 \mu \mathrm{m}$ after only $10 \mathrm{~min}$ incubation, which could either suggest very rapid uptake and saturation, or substrate contamination. Evaluation of control samples (killed with 100\% TCA final concentration) suggest that up to $0.3 \%$ of the added ${ }^{14} \mathrm{C}$-labelled methanol (after addition of $100 \mathrm{nM}$ ) is recovered on the filters, which is attributed to either nonspecific adsorption to surfaces (including the filter), or stock contamination.

Methanol oxidation an the shelf station (station 1, Figure 1) was linear for $\sim 18 \mathrm{~h}$ at a rate of $0.007 \mathrm{nCi} \mathrm{ml}^{-1} \mathrm{~h}^{-1}\left(R^{2}=0.996, \quad n=6\right)$ after which $8 \%$ of the added label (10 nM final concentration) had been used, which increased to $12 \%$ after $24 \mathrm{~h}$ (Figure 2b). Uptake into particles $(>0.2 \mu \mathrm{m})$ was linear for the same time period at a lower rate of $0.002 \mathrm{nCi} \mathrm{ml}^{-1} \mathrm{~h}^{-1}\left(R^{2}=0.989, \quad n=6\right)$. After $18 \mathrm{~h}$ $2.3 \%$ of the added label was counted in the particles, which increased to $3.5 \%$ after $24 \mathrm{~h}$.

At the more oceanic, low chlorophyll $a$ stations (station 2 and 3, Table 1), rates of incorporation of added label into particles were very low. At station 2 only $\sim 0.4 \%$ of the added label was found in the particles after $26 \mathrm{~h}$. At station 3, uptake into particles was linear for up to $12 \mathrm{~h}$ at a very low rate of $0.001 \mathrm{nCi} \mathrm{ml}^{-1} \mathrm{~h}^{-1}\left(R^{2}=0.994 n=5\right)$, after which only $0.07 \%$ of the added label (100 nM final concentration) had been used.

Rates of methanol oxidation in $\mathrm{nmoll}^{-1}$ day $^{-1}$ were calculated from the product of the apparent rate constant, $k \times C$, where $C=$ concentration (nM) of ${ }^{14} \mathrm{CH}_{3} \mathrm{OH}$ (Connell et al., 1997), and are summarised in Table 2. The in situ concentrations of methanol are not known, however, we have recently determined that the surface concentration of methanol at L4 was $97 \pm 8 \mathrm{nM}(n=4)$ between May and June 2010, and for the wider temperate north Atlantic waters was $70 \pm 13 \mathrm{nM}(n=6)$. Analysis was performed using a membrane-inlet system coupled to detection by proton-transfer mass spectrometry. These concentrations are within the range quoted by Williams et al. (2004), for surface waters of $118 \pm 48 \mathrm{nmol}^{-1}$ for the tropical north Atlantic. This remains the only published seawater methanol dataset. We have therefore estimated methanol turnover times of 12-23 day at the coastal station, 24 day at the shelf break and between 11 and 33 day at a lower productivity offshore oceanic site (station 7a) in the northeast Atlantic (Figure 1).

\section{Uptake kinetics}

The microbial uptake of ${ }^{14} \mathrm{CH}_{3} \mathrm{OH}$ typically displayed non-saturation type kinetics for rates of methanol oxidation, and uptake onto particles for additions of methanol up to $250 \mathrm{nmoll}^{-1}$. However, when the data was plotted using the Lineweaver-Burk transformation (double reciprocal plot), linear relationships were found to explain between 74 and $99 \%$ of the variance in the data (Figure 3), enabling the first estimates of $V_{\max }$ and $K_{\mathrm{m}}$ to be determined (Table 3). Total microbial methanol oxidation $V_{\max }$ of between 1.0 and $1.2 \mathrm{nmoll}^{-1} \mathrm{~h}^{-1}$ were found for the coastal station L4, with $K_{\mathrm{m}}$ between 9.3 and $86 \mathrm{nmoll}^{-1}$. Methanol uptake into particles at L4 showed a lower range for $V_{\max }$ between 0.20 and $0.26 \mathrm{nmoll}^{-1} \mathrm{~h}^{-1}$, with $K_{\mathrm{m}}$ values between 6.9 and $43 \mathrm{nmoll}^{-1}$.

The range in $V_{\max }$ found for methanol uptake into particles for stations 2 and 3 in the northeast Atlantic was approximately three times lower compared with the coastal station ranging between 0.06 and $0.07 \mathrm{nmol}^{-1} \mathrm{~h}^{-1}$. The $K_{\mathrm{m}}$ value at station 3 was notably high at $974 \mathrm{nmol} \mathrm{l}^{-1}$, suggesting that the microbial population at this station had a much lower affinity for incorporating methanol into cellular biomass.

\section{Addition and inhibitor experiments}

The addition of TMA (10-100 $\mu \mathrm{M})$ to surface coastal seawater samples (L4) did not significantly change 

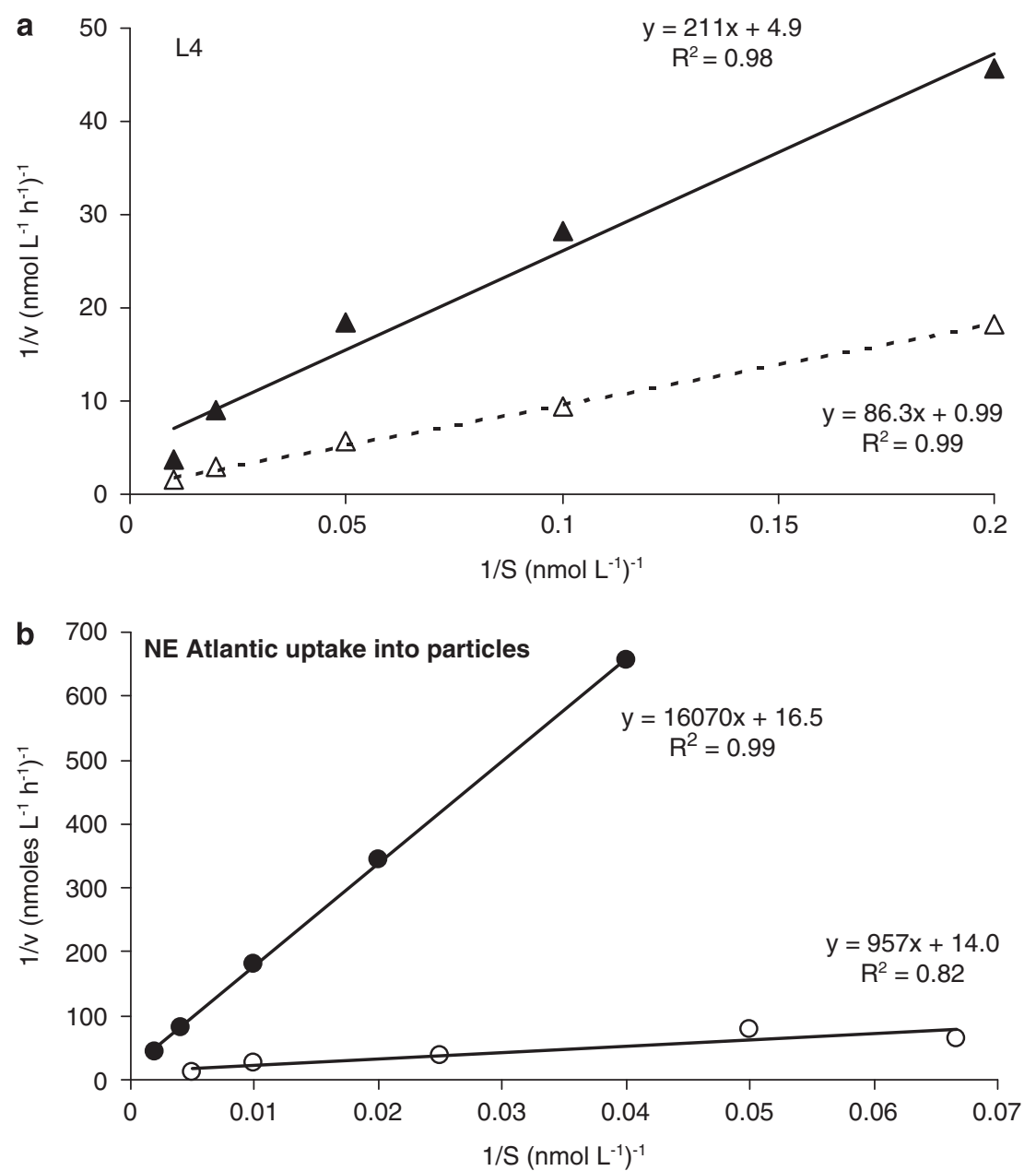

Figure 3 Lineweaver-Burke plots showing methanol uptake at (a) the coastal station L4 after $24 \mathrm{~h}$ incubation for particles ( $\mathbf{\Delta})$ and oxidation $(\Delta)$, and $(\mathbf{b})$ stations $2(\bigcirc)$ and $3(\bullet)$ in the northeast Atlantic for uptake into particles only.

Table 3 Kinetic parameters for ${ }^{14} \mathrm{CH}_{3} \mathrm{OH}$ uptake in surface seawater (using Lineweaver-Burk plots) compared with other common microbial carbon and nitrogen sources

\begin{tabular}{|c|c|c|c|c|c|c|}
\hline Substrate & Description & $\begin{array}{c}\mathrm{V}_{\max } \\
\left(\mathrm{nmol} \mathrm{l^{-1 }} h^{-1}\right)\end{array}$ & $\begin{array}{c}\mathrm{K}_{m} \\
\left(\mathrm{nmol} \mathrm{l} \mathbf{l}^{-1}\right)\end{array}$ & $\begin{array}{l}\mathrm{V}_{\max }: \\
K_{m} \text { ratio }\end{array}$ & Location & Reference \\
\hline \multirow[t]{3}{*}{ Methanol } & Total $^{\mathrm{a}}$ & $1.0-1.2$ & $9.3-86$ & $0.01-0.13$ & Coastal surface water (L4) & This study \\
\hline & Particles $^{\mathrm{a}}$ & $0.20-0.26$ & $6.9-43$ & $0.005-0.04$ & Coastal surface water (L4) & This study \\
\hline & Particles $^{\mathrm{b}}$ & $0.06-0.07$ & $68-974$ & $\leqslant 0.001$ & $\begin{array}{l}\text { Northeast Atlantic surface water } \\
\text { (stations } 2 \text { and 3) }\end{array}$ & This study \\
\hline \multirow{4}{*}{$\begin{array}{l}\text { Proteins } \\
\text { (proteolytic) }\end{array}$} & Total & 88 & 70000 & 0.001 & Northeast Atlantic surface water & Davey et al. (2001) \\
\hline & Particles & 70 & & & Northeast Atlantic surface water & Davey et al. (2001) \\
\hline & Total & $4.35-33.7$ & $210-1030$ & $0.01-0.02$ & Ross Sea, surface layers & Misic et al. (2002) \\
\hline & Particles & $0.89-23.4$ & $400-1000$ & $0.002-0.05$ & Ross Sea, surface layers & Misic et al. (2002) \\
\hline \multirow[t]{2}{*}{$\begin{array}{l}\text { Carbohydrates } \\
\text { (glycolytic) }\end{array}$} & $\begin{array}{l}\text { Cellulose } \\
\text { particles }\end{array}$ & $0.08-0.92$ & $230-1250$ & $<0.001-0.002$ & Ross Sea, surface layers & Misic et al. (2002) \\
\hline & Chitin, particles & $0.17-0.58$ & $50-200$ & $0.002-0.004$ & Ross Sea, surface layers & Misic et al. (2002) \\
\hline
\end{tabular}

a Range found between 3 and $24 \mathrm{~h}$ incubation.

${ }^{\mathrm{b}}$ Added ${ }^{14} \mathrm{C}$ methanol concentrations $<15$ and $25 \mathrm{nM}$ for stations 2 and 3 , respectively, were not used to calculate kinetic parameters.

the rate of uptake of ${ }^{14} \mathrm{C}$-labelled methanol into particles $\left(0.006 \pm 0.001 \mathrm{nCi} \mathrm{ml}^{-1} \mathrm{~h}^{-1}\right.$, Figure 4a) during the first $24 \mathrm{~h}$ of the incubation. Thereafter, the addition of TMA increased uptake rates, with a maximum of $0.01 \mathrm{nCiml}^{-1} \mathrm{~h}^{-1}$ found after the addition of $50 \mu \mathrm{M}$. In contrast, the addition of TMA 
a
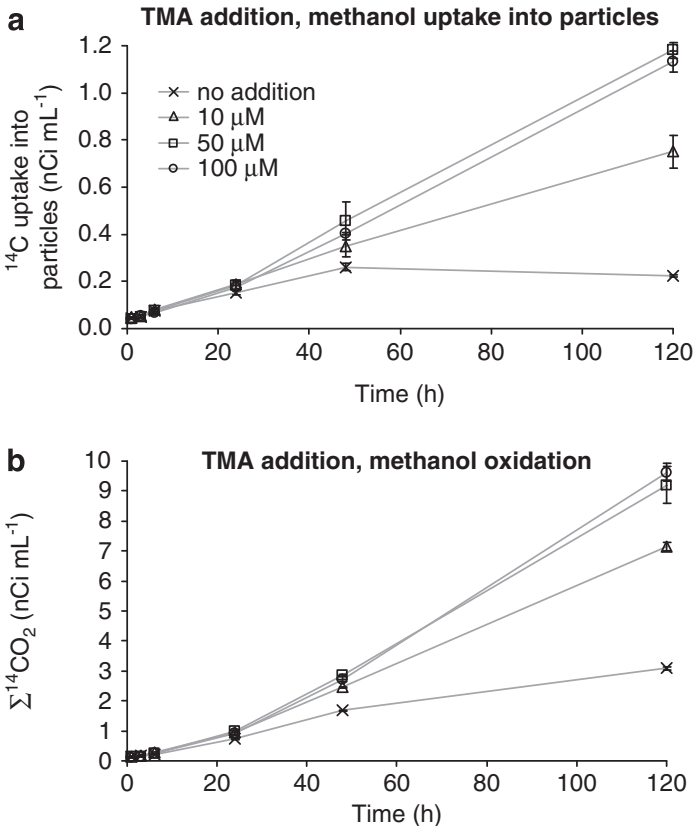

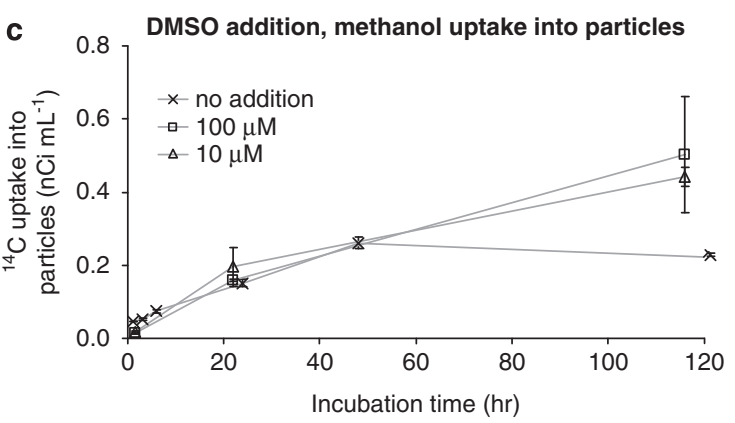

d

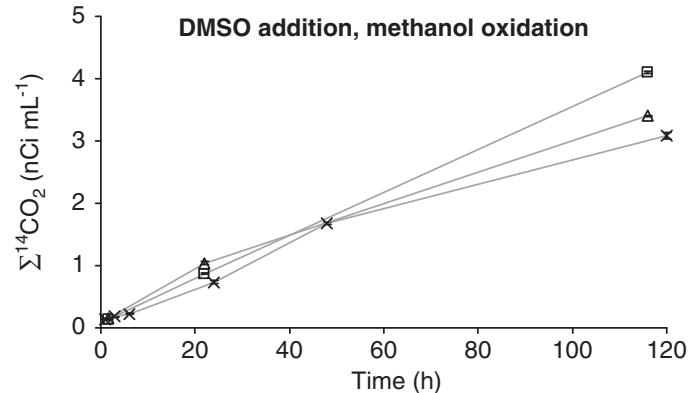

Figure 4 Time course experiments of ${ }^{14} \mathrm{CH}_{3} \mathrm{OH}$ uptake into particulate biomass and oxidation after addition of (a and $\left.\mathbf{b}\right)$ TMA between 10 and $100 \mu \mathrm{M}$ and (c and d), dimethyl sulfoxide (DMSO, 10 and $100 \mu \mathrm{M}$ ). Error bars show \pm 1 s.d.

did slightly increase the rate of oxidation of ${ }^{14} \mathrm{CH}_{3} \mathrm{OH}$ to ${ }^{14} \mathrm{CO}_{2}$ during the first $24 \mathrm{~h}$ (Figure $4 \mathrm{~b}$ ) from $0.03 \mathrm{nCi} \mathrm{ml}^{-1} \mathrm{~h}^{-1}$ (no addition) to $0.04 \pm$ $0.003 \mathrm{nCi} \mathrm{ml}^{-1} \mathrm{~h}^{-1}$. The maximum rate of methanol oxidation (with TMA) was $0.09 \pm 0.004 \mathrm{nCi} \mathrm{ml}^{-1} \mathrm{~h}^{-1}$ after addition of 50-100 $\mu \mathrm{M}$ TMA (between 1 and 5 days incubation), which suggests that the addition of TMA increased methanol oxidation approximately threefold compared with samples without TMA. Methanol uptake rates (into particles or oxidation) were not measurable when samples were killed with TCA ( $5 \%$ final concentration).

The addition of dimethylsulphoxide resulted in rates of methanol uptake into particles and its oxidation of $0.004 \pm 0.0004$ and $0.03 \pm 0.005$ $\mathrm{nCiml}^{-1} \mathrm{~h}^{-1}$, respectively, (average of 10 and $100 \mu \mathrm{M}$ additions). These rates were sustained for up to 5 days compared with unamended samples, whose utilisation rates decreased after $48 \mathrm{~h}$ incubation. The addition of prokaryotic (chloroamphenicol) and eukaryotic (cycloheximide) inhibitors reduced the uptake of methanol into biomass by $>95 \%$ and its oxidation by between 67 and $83 \%$ (Figure 5).

\section{Latitudinal trends in the northeast Atlantic}

The uptake rates of ${ }^{14} \mathrm{CH}_{3} \mathrm{OH}$ into particulate biomass from surface seawater samples, (shown as $k$ ) were plotted with corresponding rates of bacterial protein synthesis according to the latitude of sampling location (Figure 6a). Numbers of heterotrophic bacteria, picoeukaryotes (Figure 6b), Synechococcus and Prochlorococcus cells are also shown (Figure 6c). Surface constants for methanol uptake into particles were typically $<0.002$ day $^{-1}$ at

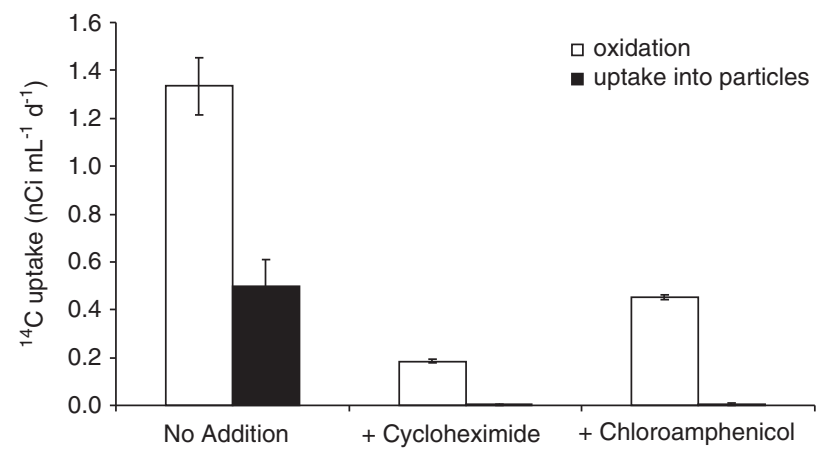

Figure 5 Rates of ${ }^{14} \mathrm{CH}_{3} \mathrm{OH}$ uptake into particulate biomass (solid bars) and oxidation to ${ }^{14} \mathrm{CO}_{2}$ (open bars) for surface coastal seawater samples (L4) after the addition of cycloheximide, a prokaryotic protein synthesis inhibitor, and chloroamphenicol, a eukaryotic protein synthesis inhibitor. Error bars show \pm 1 s.d.

the low chlorophyll $a\left(<0.2 \mu \mathrm{gl}^{-1}\right.$, Table 1$)$ stations located $\sim 43^{\circ} \mathrm{N}$. There was an exception to this at station $4\left(43.7{ }^{\circ} \mathrm{N}\right.$, Table 1$)$, where an anomalously higher methanol uptake rate constant of 0.012 day $^{-1}$ was coincident with an unusually high bacterial protein synthesis of $531 \mathrm{pMLeu}$ day $^{-1}$, compared with an average of $137 \mathrm{pMLeu}^{\mathrm{p}} \mathrm{day}^{-1}$ in this area.

Methanol uptake rates into particles and bacterial leucine incorporation generally increased in a northerly direction up 0.017 day $^{-1}$ and $684 \mathrm{pMLeu}$ day $^{-1}$, respectively, at $54^{\circ} \mathrm{N}$. Surface concentrations of chlorophyll $a$ also increased northerly from $<0.2 \mu \mathrm{g} \mathrm{l}{ }^{-1}$ at $43{ }^{\circ} \mathrm{N}$ to $0.7-1.0 \mu g l^{-1}$ at $54{ }^{\circ} \mathrm{N}$ (Table 1). Linear regression analysis shows positive correlations between methanol uptake into particles and numbers of heterotrophic bacteria $(r=0.8796$, 

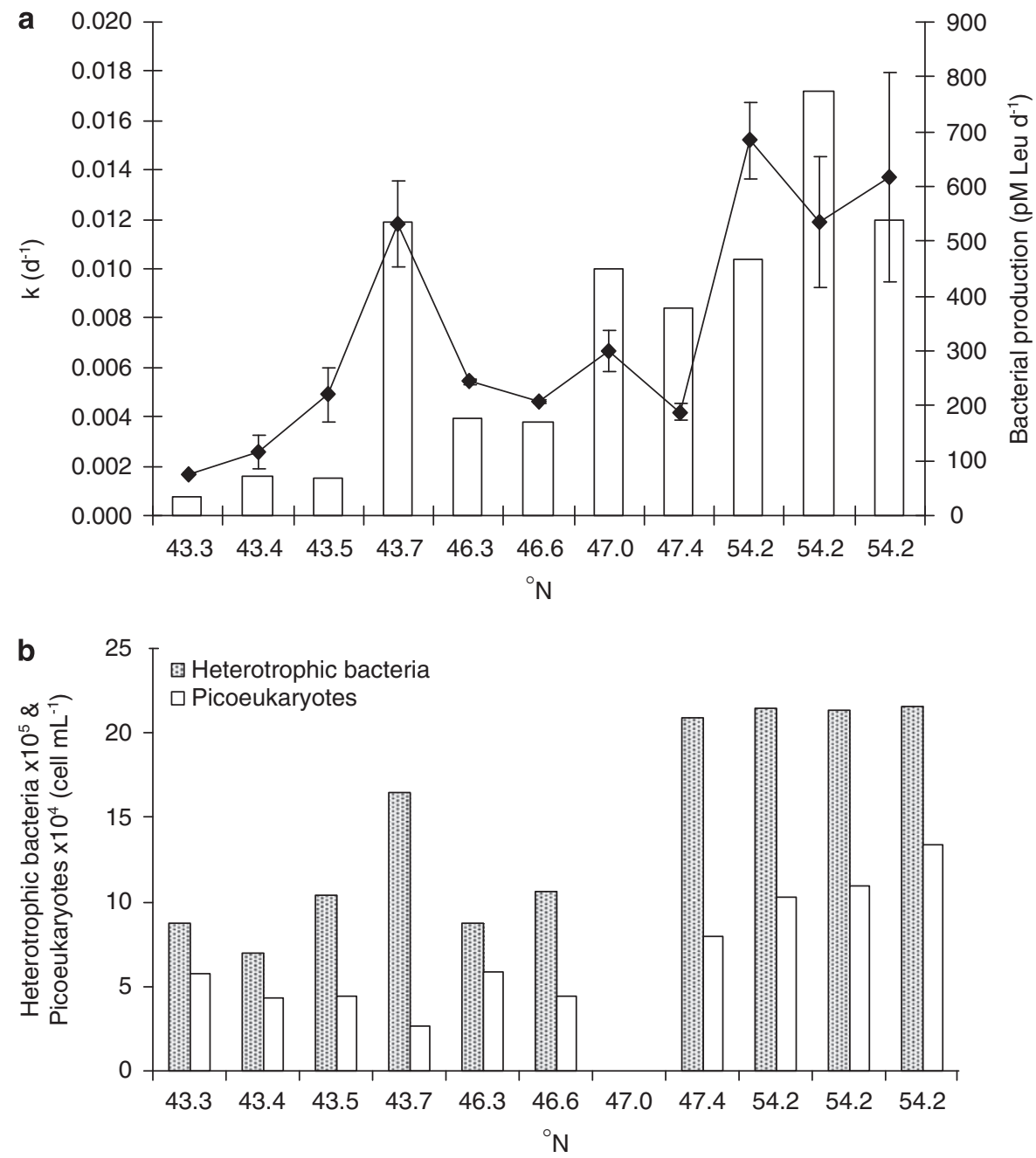

C

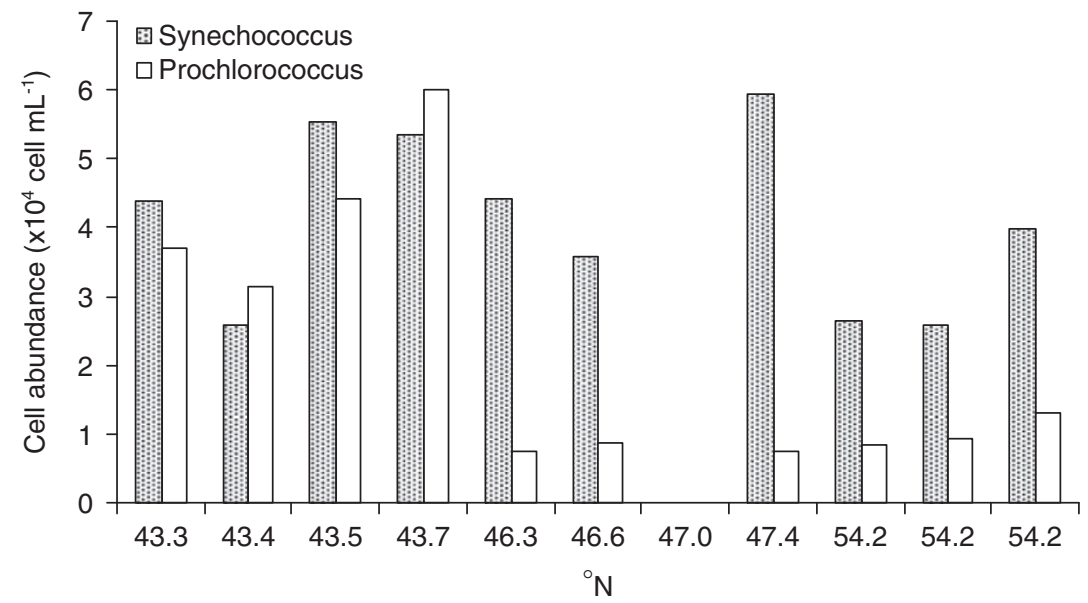

Figure 6 (a) Apparent rate constant $(k)$ for the uptake of ${ }^{14} \mathrm{CH}_{3} \mathrm{OH}$ into particulate biomass and the bacterial incorporation of ${ }^{3} \mathrm{H}-$ leucine, (b) surface numbers of heterotrophic bacteria and picoeukaryotes and (c) surface numbers of Synechococcus and Prochlorococcus plotted as a function of ${ }^{\circ} \mathrm{N}$ latitude in the northeast Atlantic. Error bars show $1 \pm$ s.d.

$n=10, P \leqslant 0.001)$, picoeukaryotes $(r=0.8398, n=10$, $P \leqslant 0.01)$, and bacterial protein production $(r=0.7153, n=11, P \leqslant 0.02)$. Although it is acknowledged that the numbers of heterotrophic bacteria, as determined by flow cytometry, could potentially include members of the Archaea, some of which could be autotropic (Meng et al., 2009). The numbers of Synechococcus or Prochlorococcus cells showed no statistically significant relationships with uptake of methanol into particles. This could 
suggest that they are not using methanol as a carbon substrate, although this is not a definitive conclusion as their cellular activities were not determined, and total numbers could include live and dead cells.

\section{Discussion}

This study is the first to show that radiolabelled methanol $\left({ }^{14} \mathrm{CH}_{3} \mathrm{OH}\right)$ can be successfully used to determine microbial uptake into biomass and oxidation in seawater samples. We have found that methanol is used predominantly as a microbial energy source, but also demonstrated that it is used as a carbon source.

For the first time, we report biological methanol oxidation rates between 2.1-8.4 $\mathrm{nM}^{-1} \mathrm{day}^{-1}$ in surface seawater of the northeast Atlantic, although kinetic experiments predict a $V_{\max }$ of up to $29 \mathrm{nmoll}^{-1}$ day $^{-1}$ in more productive coastal waters. The lower range in $K_{\mathrm{m}}$ values found for methanol uptake in particles compared with its oxidation rates suggests that the microbial enzymes used in converting methanol into cellular carbon $\left({ }^{14} \mathrm{C}\right.$-macromolecular incorporation) have a slightly higher affinity for the substrate, compared with the enzyme systems involved in using methanol as an energy source, and its ultimate respiration to ${ }^{14} \mathrm{CO}_{2}$. It is useful to distinguish between total microbial use of methanol, and the uptake into particulate fractions so that we can estimate how significant methanol is as a carbon source for cell growth, in addition to its use as an energy source. Methlyotrophic bacteria must use $\mathrm{C}_{1}$ compounds more reduced than $\mathrm{CO}_{2}$ as sole energy sources, and to assimilate carbon into cell biomass (Murrell and McDonald, 2000). Both pathways initially oxidise methanol to formaldehyde in the cell using the enzyme methanol dehydrogenase. Thereafter, incorporation into cell material is thought to proceed either via the RuMP or serine cycle into 3-carbon compounds and ultimately to cell material (Murrell and McDonald, 2000). If methanol is used as a source of energy, then formaldehyde is further oxidised in the cell to formic acid with the enzyme formaldehyde dehydrogenase, before being respired to $\mathrm{CO}_{2}$ using the enzyme formate dehydrogenase. Our kinetic experiments determine the amount of ${ }^{14} \mathrm{C}$ retained in the particulate phase and the amount respired to ${ }^{14} \mathrm{CO}_{2}$, which we assume is representative of cellular incorporation (cell growth) and energy use respectively. However, both end processes measured will have inevitably been the resultant actions of more than one enzyme.

The calculated $V_{\max }$ rates and $K_{\mathrm{m}}$ constants derived from Figure 3 assume saturation of a single enzyme (Michaelis-Menten kinetics), which unfortunately was not confirmed by our additions of ${ }^{14} \mathrm{C}$-labelled methanol up to $250 \mathrm{nmoll}^{-1}$. These non-saturation kinetics could imply that there is no active enzyme transport system for methanol. However, when samples were killed with TCA ( $5 \%$ final concentration), methanol uptake did not increase over time, which suggests that despite a possible lack of an active transport system, the uptake was nevertheless because of microbial metabolic activity. Jennings (1963) points out that if the absorption of a solute, for example, methanol is the result of metabolic activity, the rate of adsorption will inevitably be describable by Michaelis-Menten kinetics, even though no specific transport system is involved, lending validity to our derived $V_{\max }$ and $K_{\mathrm{m}}$ results. Furthermore, it is highly likely that methanol uptake by natural microbial communities in seawater results not only from bacteria, but also from mixotrophic and heterotrophic phytoplankton. This is evident from the multiphasic uptake kinetics particularly shown by methanol uptake onto particles for L4 and stations 2 and 3 (Figure 7). Wright and Hobbie (1966) suggested that at very low concentrations of substrate, most glucose was incorporated because of the active transport systems in bacteria, whereas at higher concentrations diffusion across algal cells dominated. Therefore, our methanol uptake onto particles (Figure 7) could suggest that bacterial transport processes dominated

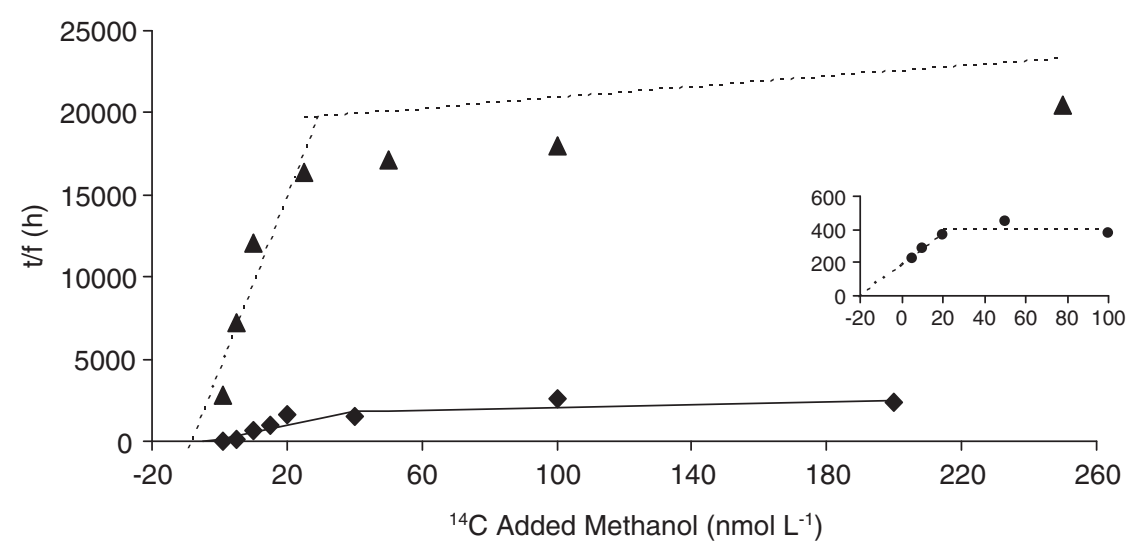

Figure 7 Modified Lineweaver-Burke plot demonstrating apparent multiphasic kinetics of methanol uptake into particles for stations $2(\checkmark)$ and $3(\boldsymbol{\Delta})$ in the northeast Atlantic, and the coastal station L4 $(\bullet)$ in the inset. Where the time of incubation $(t)$ divided by the fraction of added label taken up $(f)$ is plotted against the concentration of added label. 
for added concentrations $\leqslant 20-30 \mathrm{nmol}^{-1}$, whereas at higher concentrations most of the incorporation was because of diffusion.

For rates of microbial methanol oxidation in nearshore coastal waters (L4), which increased linearly with substrate concentration $(y=0.006 \times+0.03$, $n=5, R^{2}=0.99$ for $24 \mathrm{~h}$ incubations, data not shown in this format) a diffusion constants $\left(K_{\mathrm{d}}\right)$ can be calculated from the slope of the linear relationship (Wright and Hobbie, 1965). This constant assumes that the organisms are incorporating the methanol as rapidly as it diffuses in (Wright and Hobbie, 1965). A $K_{\mathrm{d}}$ of $0.006 \mathrm{~h}^{-1}$ is equivalent to a turnover time of 7 days (Wright and Hobbie, 1965). This estimated turnover time is not dependant on an assumed in situ surface seawater concentration of methanol, and suggests a faster turnover compared with the previous estimates of 12-23 days (as in Table 2 calculations). It is also closer to the $\sim 3$ day estimate, which was based on the turnover of other compounds, such dimethylsulphide from the literature (Heikes et al., 2002). The seawater sampled for the kinetic experiments contained high numbers of Prorocentrum minimum, who are mixotrophic species (Stoecker, 1999), so could be contributing via methanol diffusing across their surface membranes, and thus contributing to a faster turnover time than predicted from Table 2. These phytoplankton could also be consuming bacterioplankton, who have previously incorporated methanol (Zubkov and Tarran, 2008).

The kinetic characteristics of microbial methanol utilisation can be compared with those of other substrates commonly used by bacteria, so that the ecological significance of methanol to marine microbial metabolism can start to be evaluated (Table 3). Proteolytic enzyme $V_{\max }$ are generally significantly greater than those of methanol, and have correspondingly higher $K_{\mathrm{m}}$ concentrations, suggesting much lower enzyme substrate affinity for proteins compared with methanol. This is perhaps to be expected considering that this enzyme activity reflects the hydrolysis of a broad range of proteins and peptides, whose concentrations in seawater are thought likely to exceed those of methanol by at least one order of magnitude. The range found in $V_{\max }$ for the hydrolysis of carbohydrates associated with particles is comparable with those of methanol uptake into particles in surface waters. The range in $K_{\mathrm{m}}$ constants for cellulose in particular, is higher than that calculated for methanol in more coastal waters, but is more similar to methanol $K_{\mathrm{m}}$ constants in particles sampled from more remote Atlantic surface waters.

The addition of TMA, as an example of a methylated amine compound, increased both methanol uptake into particles and oxidation at the coastal L4 station. This suggests that TMA induced methylotrophic pathways, indicating that the bacteria utilising methanol (presumably via methanol dehydrogenase) were also capable of incorporating methylated amines, and thus were likely to contain methylated amine dehydrogenases and methylamine oxidase (Murrell and McDonald, 2000). Interestingly, the predominance of Methylophaga spp in the consumption of both methanol and methylamine at L4 has been reported by Neufeld et al. (2007). The addition of dimethylsulphoxide, as an example of a methylated sulphur compound, suggested that sulphur utilising methylotrophs in surface seawater at L4 also incorporated methanol as a carbon and energy source, and can perhaps outcompete non-sulphur utilising methlyotrophs over longer incubation times, when presumably nutrients deplete. Some methylotrophic bacteria, such as Hyphomicrobium, are known to be capable of using compounds, such as dimethylsulphoxide and so on, via the serine pathway (Murrell and McDonald, 2000). We have consistently identified Hyphomicrobium spp from all the DNA samples collected between $35^{\circ} \mathrm{N}$ and $30^{\circ} \mathrm{S}$ in the Atlantic Ocean from $200 \mathrm{~m}$ depth (S Sargeant, personal communication). These addition experiments suggest that microbes use methanol mainly as an energy source, and only $\sim 12 \%$ of the uptake is attributable to meeting cellular carbon requirements.

The identification of the organisms involved in $\mathrm{C}_{1}$ uptake and linking this specifically to function can be further achieved using DNA-stable-isotope probing (Neufeld et al., 2007, 2008). Using these techniques at L4, and in the western English Channel, Neufeld et al. $(2007,2008)$ in addition to Methylophaga spp, have unexpectedly found sequences from undescribed gammaproteobacteria that use methanol, methylamines and dimethylsulphide. These bacteria have no cultured representatives and suggest ecological adaptation of particular methylotrophs to specific $\mathrm{C}_{1}$ compounds in the coastal marine environment (Neufeld et al., 2007).

The reduction in the uptake of methanol into the particulate phase and its oxidation with additions of chloroamphenicol and cycloheximide suggests that not only prokaryotic bacteria, but also perhaps eukaryotic cells use methanol for carbon and energy. In contrast, Goodwin et al. (1997) reported that cycloheximide had no effect on dibromomethane oxidation rates in seawater. We have also found positive linear correlations between uptake of methanol into particulate material and the numbers of heterotrophic bacteria and picoeukaryotes and heterotrophic bacterial production. Additionally, we demonstrated a clear pattern of increasing methanol uptake into particles with increasing chlorophyll $a$ concentrations.

This research now offers methanol loss rates from seawater, for the first time, which will improve the understanding of the global methanol budget and may have implications for bacterial productivity.

\section{Acknowledgements}

We wish to thank all the scientists and crew onboard RRS Discovery during the D320 cruise. In addition, I would 
like to thank Stephanie Sargeant for the DNA sequencing, Glen Tarran for his help with the flow cytometer, and Claire Widdicombe for the phytoplankton and chlorophyll $a$ analysis at L4, which is provided by the Plymouth Marine Laboratory Western Channel Observatory (http://www.westernchannelobservatory.org.uk), and is funded by the NERC Oceans 2025 Sustained Observatories theme. Satellite data were processed by the NERC Earth Observation Data Acquisition and Analysis Service (NEODAAS) at Plymouth Marine Laboratory (http://www. neodaas.ac.uk). This work was funded by the Surface Ocean Lower Atmosphere Study UK project NE/C517192/ 1 and by OCEANS 2025, Plymouth Marine Laboratories NERC funded core research programme.

\section{References}

Carpenter LJ, Lewis A, Hopkins JR, Read KA, Longley ID, Gallagher MW. (2004). Uptake of methanol to the north Atlantic Ocean surface. Global Biogeochem Cycles 18: GB4027.

Connell T, Joye SB, Miller LG, Oremland RS. (1997). Bacterial oxidation of methyl bromide in Mono Lake, California. Environ Sci Technol 31: 1489-1495.

Davey KE, Kirby RR, Turle CM, Weightman AR, Fry JC. (2001). Depth variation of bacterial extracellular enzyme activity and population diversity in the northeastern North Atlantic ocean. Deep Sea Res II 48: 1003-1017.

Galbally IE, Kirstine W. (2002). The production of methanol by flowering plants and the global cycle of methanol. J Atmos Chem 43: 195-229.

Goodwin KD, Lidstrom ME, Oremland RS. (1997). Marine bacteria degradation of brominated methanes. Environ Sci Technol 31: 3188-3192.

Goodwin KD, Schaefer JK, Oremland RS. (1998). Bacterial oxidation of dibromomethane and methyl bromide in natural waters and enrichement cultures. Appl Environ Microbiol 64: 4629-4636.

Heikes BG, Chang W, Pilson ME, Swift E, Singh HB, Guenther A et al. (2002). Atmospheric methanol budget and ocean implication. Global Biogeochemical Cycles 16: 1133.

Holm-Hansen O, Lorenzen CJ, Holmes RW, Strickland JDH. (1965). Fluorometric determinations of chlorophyll. Journal $d u$ Conseil Permenant International pour l'Exploration de la Mer 30: 3-15.

Jennings DH. (1963). The Absorption of Solutes by Plant Cells. Oliver and Boyd: London, 204p.

Kiene RP. (1993). Microbial sources and sinks for methylated sulfur compounds in the marine environment. In: Kelly DP, Murrell JC (eds). Microbial Growth on C1 Compounds. Intercept Ltd.: London, pp 15-33.

Kiene RP, Hoffmann Williams LP. (1998). Glycine betaine uptake, retention, and degradation by microorganisms in seawater. Limnol Oceanogr 43: 1592-1603.

Marie D, Partensky F, Jacquet S, Vaulot R. (1997). Enumeration and cell analysis of natural populations of marine picoplankton by flow cytometry using the nucleic acid strain SYBR Green I. Appl Environ Microbiol 63: 186-193.

Meng J, Wang F, Wang F, Zheng Y, Peng X, Zhou H et al. (2009). An uncultivated crenarchaeota contains functional bacteriochlorophyll a synthase. ISME J 3: 106-116.

Milne PJ, Riemer DD, Zika RG, Brand LE. (1995). Measurement of vertical distribution of isoprene in surface seawater, its chemical fate, and its emission from several phytoplankton monocultures. Mar Chem 48: 237-244.

Misic C, Povero P, Fabiano M. (2002). Ectoenzyme rations in relation to particulate organic matter distribution (Ross Sea, Antartica). Microb Ecol 44: 224-234.

Murrell JC, McDonald IR. (2000). Methylotrophy. In: Lederberg, J (ed). Encyclopedia of Microbiology second edn. Academic Press: London, pp 245-255.

Neufeld JD, Boden R, Moussard H, Schäfer H, Murrell JC. (2008). Substrate-specific caldes of active marine methylotrophs associated with a phytoplankton bloom in a temperate coastal environment. Appl Environ Microbiol 74: 7321-7328.

Neufeld JD, Schäfer H, Cox MJ, Boden R, McDonald IR, Murrell JC. (2007). Stable-isotope probming implicates Methylophaga spp abd novel gammaproteobacteria in marine methanol and methylamine metabolism. ISME J 1: 480-491.

Nightingale PD. (1991). Low Molecular Weight Halocarbons in Seawater PhD thesis. University of East Anglia: Norwich, UK.

Sieburth JM, Keller MD. (1989). Methylaminotrophic bacteria in xenic nanoalgal cultures: incidence, significance, and role of methylated algal osmoprotectants. Biol Oceanogr 6: 383-395.

Singh HB, Kanakidou M, Crutzen PJ, Jacob DJ. (1995). High concentrations and photochemical fate of oxygenated hydrocarbons in the global troposhere. Nature 378: 51-54.

Singh H, Chen Y, Tabazadeh T, Fukui Y, Bey I, Yantosca R et al. (2000). Distribution and fate of selected oxygenated organic species in the troposphere and lower stratosphere over the Atlantic. J Geophys Res 105: 3795-3805.

Singh H, Chen Y, Staudt A, Jacob D, Blake D, Heikes B et al. (2001). Evidence from the Pacific troposphere for large global sources of oxygenated organic compounds. Nature 410: 1078-1081.

Singh H, Tabazadeh A, Evans MJ, Field BD, Jacob DJ, Sachse G et al. (2003). Oxygenated volatile organic chemicals in the oceans: inferences and implications based on atmospheric obseravtions and air-sea exchange models. Geophys Res Letts 30: 1862.

Smith DC, Azam F. (1992). A simple, economical method for measuring bacterial protein synthesis rates in seawater using ${ }^{3} \mathrm{H}$-leucine. Mar Microb Food Webs 6: 107-114.

Smith TJ, Murrell C. (2009). Methanotrophy/methane oxidation. In: Schaechter M (ed). Encylopedia of Microbiology. Elsevier: Oxford, pp 293-298.

Stoecker DK. (1999). Mixotrophy among Dinoflagellates. J Eukaryot Microbiol 46: 397-401.

Wennberg PO, Hanisco TF, Jaeglé L, Jacob DJ, Hintsa EJ, Lanzendorf EJ et al. (1998). Hydrogen radicals, nitrogen radicals, and the production of ozone in the upper troposphere. Science 279: 49-53.

Williams J, Holzinger R, Gros V, Xu X, Atlas E, Wallace DWR. (2004). Measurements of organic species in air and seawater from the reopical Atlantic. Geophys Res Letts 31: LS23S06.

Wright RT, Hobbie JE. (1965). The uptake of organic solutes in lake water. Limnol Oceanogr 10: 22-28. 
Wright RT, Hobbie JE. (1966). Use of glucose and acetate by bacteria and algae in aquatic ecosystems. Ecology 47: 447-464.

Zubkov MV, Sleigh MA, Burkhill PH, R Leakey JG. (2000). Picoplankton community structure on the Atlantic
Meridional transect: a comparison between seasons. Prog Oceanogr 45: 369-386.

Zubkov MV, Tarran GA. (2008). High bacterivory by the smallest phytoplankton in the the North Atlantic Ocean. Nature 455: 224-226. 